\title{
The Efficiency of Garlic Supply Chain Actors Measured using Data Envelopment Analysis (DEA) Method in Karanganyar, Indonesia
}

\author{
Betha Wahyuningtyas $^{1 *}$, Kusnandar ${ }^{2}$ and Sutrisno Hadi Purnomo ${ }^{3}$ \\ ${ }^{1}$ Department of Agribusiness, Postgraduate Program, Universitas Sebelas Maret, Surakarta, Indonesia; \\ ${ }^{2}$ Department of Agribusiness, Faculty of Agriculture, Universitas Sebelas Maret, Surakarta, Indonesia; \\ ${ }^{3}$ Department of Animal Science, Faculty of Agriculture, Universitas Sebelas Maret, Surakarta, Indonesia
}

${ }^{*}$ Corresponding author: betha1302@gmail.com

\begin{abstract}
One of the obstacles to the development of agribusiness is related to supply chain management. The availability of supply is the most important factor in influencing supply chain performance. Without a stable and routine supply, supply chain performance will be disrupted. Karanganyar Regency is one of the production centers of horticultural commodities, particularly garlic. This study aimed to analyze the efficiency of each garlic supply chain actor in Karanganyar Regency. The research was conducted from March to April 2019. The efficiency of each supply chain actor in this study was measured using Data Envelopment Analysis (DEA) method. Performance measurement was done through the DEA approach and the performance attributes were input and output variables. The respondents observed were 50 farmers and 13 supply chain actors working in institutions. The samples of farmers were taken using purposive sampling technique, while the samples of supply chain actors were obtained using snowball sampling. The results have shown that the most efficient supply chain actors were retailers with an efficiency value of $1(100 \%)$, while inefficient supply chain actors were farmers with an average efficiency value of 0.709 . From a total of 50 Decision Making Unit (DMU) of total farmers, 13 DMU (26\%) were efficient, while 37 DMU (74\%) were inefficient and further need improvements, like using certified seeds and suitable fertilizer recommendations, as well as reducing external labor during the process of maintenance, harvesting and post-harvest. Farmers are expected to have the desire to learn from referral farmers.
\end{abstract}

Keywords: garlic production; optimization; performance

Cite this as: Wahyuningtyas, B., Kusnandar, \& Purnomo, S. H. (2020). The Efficiency of Garlic Supply Chain Actors Measured using Data Envelopment Analysis (DEA) Method in Karanganyar, Indonesia. Caraka Tani: Journal of Sustainable Agriculture, 35(2), 168-179. doi: http://dx.doi.org/10.20961/carakatani.v35i2.33114

\section{INTRODUCTION}

Garlic (Allium sativum L.) is one of the seasonal plants and is the most popular spice in the world (Haciseferoğullari et al., 2005; Wu et al., 2015; Petropoulos et al., 2018). Garlic has a distinctive aroma and texture (Benkeblia, 2004). The current centers of garlic production in Indonesia include West Nusa Tenggara, Central Java, West Java, Special Region of Yogyakarta, West Sumatra and East Java. The main garlic producing regions in Central Java Province comprise Cilacap, Purbalingga, Wonosobo, Magelang, Karanganyar, Semarang, Temanggung, Kendal, Batang, Tegal and Brebes Regencies (Appendix 1).

A fundamental aspect of agribusiness of horticultural products is linked to supply chain management. Supply chain is correlated with the flow and transformation of goods and services, starting from the stage of providing raw materials

\footnotetext{
* Received for publication July 30, 2019

Accepted after corrections February 27, 2020
} 
until the distribution of the final product to consumers (Furqon, 2014). Supply chain management is the unity of the initial actors developing in the distribution network with internal activities and supply data, so that it greatly affects the performance of a sustainable supply chain organization (Bastas and Liyanage, 2018). It is an integrated approach, started with the planning and controlling of materials, logistics, services and flows of information from suppliers to producers or to the end-consumers (Fantazy et al., 2010).

The research on supply chain performance conducted by Sari et al. (2014), in Losarang Subdistrict, Indramayu Regency, analyzed the efficiency of catfish supply chain performance. The results of the study have shown that the performance of farmers belonging to the dealer partner of farmer's groups was not efficient, while the supply chain performance of farmers, companies and dealers was fairly efficient.

Supply chain management includes a range of approaches and practices to effectively integrate suppliers, producers, distributors and customers to improve the long-term performance of each company and the overall supply chain in a cohesive and high-performance business model (Chopra and Meindl, 2001). Successful implementation of supply chain management is expected to advance relations between upstream and downstream suppliers and thus increasing customer satis-faction and company performance (Ibrahim and Hamid, 2012).

The level or quality of the garlic that varies as well as the cost of varying garlic supply chain activities is a very influential factor on the level of income which in turn will affect the sustainability of the garlic supply chain in Karanganyar Regency. The amount of costs that must be paid by each supply chain actor will have an effect on the level of income which in turn will affect the level of efficiency of each actor in the garlic supply chain.

Cost variations incurred by each farmer to meet his/her farm, including the costs of purchasing seeds, fertilizers, pesticides and labor can affect production and income, which in turn puts effect on farmers' efficiency. At the level of the collectors, the costs, consisting of the expenses for buying garlic, loading and unloading garlic, drying garlic and transportation costs will vary based on the distance of location, quality and time of buying or selling garlic to the next supply chain.
Supply availability is the most important factor in influencing the performance of the garlic supply chain, because without a stable and routine supply, the performance of the garlic supply chain will be disrupted. Product quality is a factor affecting the supply chain performance, since product quality is closely related to the level of demand for garlic consumers. The performance of the garlic supply chain in Karanganyar Regency is strongly influenced by the efficiency of the performance of each garlic supply chain actor at each supply chain level. Performance measurement in the supply chain is focused on the actors involved in it (Sigala, 2008). Garlic supply chain performance can be seen through the efficiency level of each supply chain Decision Making Unit (DMU).

The method used to measure the efficiency is Data Envelopment Analysis (DEA). According to (Thakkar et al., 2009), DEA is a method for optimizing mathematical programs that measure the efficiency of a DMU technique and compare it relatively to other DMUs. DEA analyzing technique is specifically designed to measure the relative efficiency of a DMU in conditions of many inputs and outputs.

DEA formulates DMU as a fractional linear program to find a solution, if the model is transformed into a linear program with weight values from input and output. Liang et al. (2006) have stated that DEA only uses three input variables, namely labor, operational costs and shipping costs, as well as two output variables, namely total sales and total profits.

O'Keeffe and Fearne (2002) have determined two elements as input variables, including depreciation of quality and utilization of labor and four output variables, comprising price management, promotion, price perception and profit. Batt (2009) have mentioned that supply chain efficiency ultimately depends on the efficiency of each chain actor and the relationships that are built between the members of the supply chain.

Sustainable agricultural productions provide environmental, economic and social benefits. In fact, the short supply chain other than reducing costs, which are cut down by decreasing the number of intermediaries that take the product from the producer to the consumer, creates a positive environmental externalities and above all, promotes the garlic in local areas. This work highlights the central role taken on by the implementation of new forms of marketing 
in the short supply chain and its importance in influencing the concept of sustainable development in the agricultural supply chain (De Fazio, 2016).

This research needs to be conducted to find out the supply data, supply chain flow and actors involved in the garlic supply chain in Karanganyar Regency. The purpose of this study was to analyze the efficiency of each garlic supply chain actor in Karanganyar Regency.

\section{MATERIALS AND METHOD}

\section{Method}

This study was carried out purposively in Karanganyar Regency, especially in four garlic producing sub-districts, including Tawangmangu, Jenawi, Ngargoyoso and Jatiyoso. Karanganyar Regency is located at an average altitude of 511 meters above sea level and has a tropical climate with temperatures of $22-31^{\circ} \mathrm{C}$. The total area of Karanganyar Regency is 77,379 ha, which consists of paddy fields (23,107 ha), non-rice farming fields (29,795 ha) and non-agricultural lands $(24,477 \mathrm{ha})$.

Data of supply were obtained from farmers and supply chain institutions, including village level collectors, sub-district level collectors, subdistrict level traders and retailers. The study was conducted from March to April 2019.

\section{Research design}

The samples of farmers were taken using the purposive sampling method. According to Sugiyono (2014), purposive sampling is a technique of determining samples with certain considerations. The criteria used are farmers who belong to farmer groups, farmers who grow garlic for consumption and farmers with farm experience of at least two years. The total samples of respondents were 50 farmers in four sub-districts.

The samples of supply chain institutions were obtained using the snowball sampling method. The sampling technique begins with several people, then extends based on the relationships with the respondents (Sadler et al., 2010; Nurdiani, 2014; Lee and Spratling, 2019). The criteria used are supply chain institutions that buy and sell consumable garlic and have a minimum of two years trading experience. A total of 13 supply chain institutions in four sub-districts were taken as the samples of respondents.

The data used in the study were primary and secondary data. Primary data were the data obtained directly from respondents through interviews using questionnaires. Secondary data were supporting data collected from relevant agencies related to the research.

\section{Characteristics of respondents}

The respondents involved in this study were farmers and supply chain institutions. The observed characteristics of farmers cover the aspects of age (Table 1), duration of farming experience (Table 2) and recent education (Table 3).

Table 1. Distribution of efficiency based on farmer's age and gender

\begin{tabular}{ccrcrc}
\hline \multirow{2}{*}{ No. } & \multirow{2}{*}{ Age group } & Male & Population & \multirow{2}{*}{ Percentage (\%) } \\
\cline { 2 - 5 } & $20 \leq \mathrm{x}<30$ & 1 & - & Total & 2 \\
1. & $30 \leq \mathrm{x}<40$ & 5 & 4 & 1 & 18 \\
2. & 23 & 2 & 9 & 50 \\
3. & $40 \leq \mathrm{x}<50$ & 8 & - & 25 & 16 \\
4. & $50 \leq \mathrm{x}<60$ & 7 & - & 7 & 14 \\
5. & $\geq 60$ & 44 & 6 & 50 & 100 \\
\hline & Total & & & &
\end{tabular}

Table 2. Distribution of efficiency based on length of farming experience

\begin{tabular}{ccrc}
\hline No. & $\begin{array}{c}\text { Length of farming } \\
\text { experience }\end{array}$ & Total & $\begin{array}{c}\text { Percentage } \\
(\%)\end{array}$ \\
\hline 1. & $\leq 10$ & 25 & 50 \\
2. & $10 \leq \mathrm{x}<20$ & 9 & 18 \\
3. & $20 \leq \mathrm{x}<30$ & 12 & 24 \\
4. & $30 \leq \mathrm{x}<40$ & 4 & 8 \\
\hline & Total & 50 & 100 \\
\hline
\end{tabular}

Table 3. Distribution of efficiency based on farmer education level

\begin{tabular}{ccrc}
\hline No. & $\begin{array}{c}\text { Educational } \\
\text { attainment }\end{array}$ & Total & $\begin{array}{c}\text { Percentage } \\
(\%)\end{array}$ \\
\hline 1. & Elementary school & 13 & 26 \\
2. & Junior high school & 23 & 46 \\
3. & Senior high school & 12 & 24 \\
4. & University & 2 & 4 \\
\hline & Total & 50 & 100 \\
\hline
\end{tabular}


The characteristics of supply chain institutions include the aspects of age (Table 4), duration of trading experience (Table 5) and recent education (Table 6).

Table 4. Distribution of efficiency based on age of supply chain institutions

\begin{tabular}{cccccc}
\hline \multirow{2}{*}{ No. } & \multirow{2}{*}{ Age group } & Male & Female & Total & \multirow{2}{*}{ Percentage $(\%)$} \\
\cline { 2 - 5 } & $20 \leq \mathrm{x}<30$ & - & - & - & - \\
2. & $30 \leq \mathrm{x}<40$ & - & - & - & - \\
2. & $40 \leq \mathrm{x}<50$ & 1 & 1 & 2 & 15.4 \\
3. & $50 \leq \mathrm{x}<60$ & 4 & 7 & 11 & 84.6 \\
\hline. & Total & 5 & 8 & 13 & 100.0 \\
\hline
\end{tabular}

Table 5. Distribution of efficiency based on the length of trading experience

\begin{tabular}{cccc}
\hline No. & $\begin{array}{c}\text { Length of trading } \\
\text { experience }\end{array}$ & Total & $\begin{array}{c}\text { Percentage } \\
(\%)\end{array}$ \\
\hline 1. & $\leq 10$ & 11 & 84.6 \\
2. & $10 \leq \mathrm{x}<20$ & 2 & 15.4 \\
3. & $20 \leq \mathrm{x}<30$ & - & - \\
4. & $30 \leq \mathrm{x}<40$ & - & - \\
\hline & Total & 13 & 100.0 \\
\hline
\end{tabular}

Table 6. Distribution of efficiency based on educational level of supply chain institution

\begin{tabular}{cccc}
\hline No. & $\begin{array}{c}\text { Educational } \\
\text { attainment }\end{array}$ & Total & $\begin{array}{c}\text { Percentage } \\
(\%)\end{array}$ \\
\hline 1. & Elementary school & - & - \\
2. & Junior high school & 6 & 46.2 \\
3. & Senior high school & 7 & 53.8 \\
4. & University & - & - \\
\hline & Total & 13 & 100.0 \\
\hline
\end{tabular}

\section{DEA}

DEA is a non-parametric approach based on linear programming assisted by DEAP 2.1 software. In this study, the assumption used was a constant return to scale which was first developed by Charnes et al. (1978) or commonly referred to as the CCR model as follows:

$$
\operatorname{Max} E_{m}=\frac{\sum_{j=1}^{J} v_{j m} y_{j m}}{\sum_{i=1}^{I} u_{i m} x_{i m}}
$$

with the provision of

$$
\begin{gathered}
0 \leq \frac{\sum_{j=1}^{J} v_{j m} y_{j m}}{\sum_{i=1}^{I} u_{i m} x_{i m}} \leq 1 ; \quad n=1,2, \ldots, N \\
v_{j m}, u_{i m} \geq 0 ; \quad i=1,2, \ldots I ; \quad j=1,2, \ldots, J
\end{gathered}
$$

Explanation:

$E_{\mathrm{m}}=$ The m-th DMU efficiency

$y_{\mathrm{jm}}=\mathrm{J}$-th output for m-th DMU

$v_{\mathrm{jm}}=$ The amount of output weight

$x_{\mathrm{im}}=$ The I-th input for m-th DMU

$u_{\mathrm{im}}=$ The amount of input weight.

The DMU is part of the DEA. Performance measurement in this study was carried out to compare the performance of one supply chain actor (DMU) with another DMU, so that the supply chains requiring improvements to measure supply chain performance could be determined. Each performance attribute had a performance indicator that was useful for identifying the performance efficiency of a supply chain. In measuring performance through the DEA approach, performance attributes included input and output variables. Input variables at the farm level were seed costs, input costs, labor costs (non-family), while the output variable were production and total income. Input variables at the supply chain level were product purchase costs, loading and unloading costs and transportation costs, while the output variable were production and total income.

\section{RESULTS AND DISCUSSION}

Indo Calculations that done using DEAP Version 2.1 software to determine the efficiency of the garlic supply chain used input variables, namely seeds, production facilities and wages of external labor, while the output variable was the production and income at the farm level. At the level of supply chain institutions the input variables used were the purchase of garlic, loading and unloading of the product, as well as drying stage and transportation, while the output variables used were the production and income. 
The results of the study show that it is necessary to reduce the input of each garlic supply chain actor in Karanganyar Regency. Baltacioglu et al. (2007) have stated that companies can benefit from reduced costs, increased revenue, increased customer satisfaction and increased shipping and product or service quality. Supply chain management operations consist of procedures and functions that are effectively integrated with suppliers of producers, distributors and customers to improve the performance of supply chains (Chopra and Meindl, 2007). Effective performance measurement does not only affect activities throughout the chain, but also evaluates the performance made by members of the supply chain (Zhang et al., 2009). Overall, efficiency of supply chain management can affect business performance (Peng wong and Yew wong, 2011; Tippayawong et al., 2016).

Based on the measurement of performance using the DEA method, the supply chain actors who must increase the most efficiency are farmers. The farmers had an average efficiency of 0.709. Of the 50 farmers' DMU, 13 DMUs (26\%) were efficient, while the remaining 37 DMUs (74\%) need to make improvements to achieve efficiency (Table 7). Sub-district collectors are some of the actors in the garlic supply chain in Karanganyar Regency who need to increase efficiency, after farmers. The average value of efficiency was 0.962 for traders of sub-district level collectors. A total of $4 \mathrm{DMU}$ collectors at the sub-district level had 2 DMUs (50\%), which were efficient, while the other 2 DMUs $(50 \%)$ need to make improvements to reach efficiency. The performance of each supply chain actor who needs to improve the efficiency of the garlic supply chain in Karanganyar Regency is as follows.

\section{Farmer supply chain efficiency improvement}

The results of the calculation of efficiency of garlic farmers DMU in Karanganyar Regency varied greatly from 0.299 to 1 with an average efficiency level of 0.709 , indicating that many DMUs need to be evaluated regarding the garlic farming and the causes of inefficiency need to be investigated. Based on the results of analysis using the DEAP 2.1 software, it is still possible to increase the output by reducing the use of inputs by the DMU, so that an efficient point can be reached. 13 DMU farmers from a total of 50 DMU farmers had an efficiency score of $1(100 \%)$ and they were peers for other farmers' DMUs. There were 11 DMUs, including P1, P8, P11, P34, P35, P40, P44, P45, P47, P49 and P50 (Table 7).

One DMU of inefficient farmers was DMU P2, which had an efficiency value of 0.725 , so it is necessary to refer to efficient DMU farmers, some of which were DMU P8, P1 and P40 to obtain efficient DMU (Table 8). The results of calculations with DEAP 2.1 software show that in DMU P2 with an efficiency value of $0.725(72.5 \%)$, there is the potential to increase the output (income) from IDR 1,113,254.000 to IDR $1,123,944.920$ by reducing the number of inputs before finally DMU P2 is at an efficient point such as P8, P1 and P40 (as a reference set). DMU P8 contributes 4.8\%, DMU P1 contributes $2.8 \%$ and DMU P40 contributes as much as $7 \%$ in increasing output and decreasing input DMU $\mathrm{P} 2$. It can be concluded that DMU P2 is recommended to choose DMU P8, P1 and P40 as the benchmarks.

Peers farmers, farmers P8, P1 and P40, have met particular characteristics, including having an average age of 40-60 years included in the productive age category with an average level of education in junior high school and having an average experience of 15 years in farming so they already have experience in farming garlic. The productive age population is the population in the age ranging between 15 and 64 years. This age population is considered capable of producing goods and services in the production process (Sukmaningrum and Imron, 2017).

The age of farmers can influence their physical ability to carry out agricultural practices related to the establishment of agricultural businesses, movements to new goals and the intensity of production (Burton, 2006). Wongnaa and Awunyo-vitor (2017) conducted a research in Ghana with the respondents aged between 20 and 75 years old in the Guinea Savannah zone. Age can affect workers' productivity for various reasons (Lovász and Rigó, 2013). Some of reasons are the farmers are more experienced, they are able to produce optimal garlic production and they have the willingness to learn and find information related to garlic farming. 
Table 7. Efficiency values and peers that become references to each DMU of farmers in Karanganyar

\begin{tabular}{|c|c|c|c|c|c|}
\hline DMU & Efficiency values & \multicolumn{4}{|c|}{ Peers } \\
\hline $\mathrm{P} 1$ & 1.000 & P1 & & & \\
\hline P2 & 0.725 & P8 & P1 & P40 & \\
\hline P3 & 0.511 & P8 & P34 & P45 & \\
\hline $\mathrm{P} 4$ & 0.652 & $\mathrm{P} 1$ & P8 & $\mathrm{P} 11$ & \\
\hline P5 & 0.548 & P34 & P8 & $\mathrm{P} 45$ & \\
\hline P6 & 1.000 & P49 & & & \\
\hline P7 & 0.637 & P1 & P8 & P11 & \\
\hline P8 & 1.000 & P8 & & & \\
\hline P9 & 0.997 & P40 & P8 & P1 & \\
\hline P10 & 0.741 & $\mathrm{P} 1$ & $\mathrm{P} 40$ & $\mathrm{P} 8$ & P11 \\
\hline P11 & 1.000 & P11 & & & \\
\hline P12 & 0.799 & P8 & P47 & P40 & P11 \\
\hline P13 & 0.794 & P8 & P11 & $\mathrm{P} 1$ & $\mathrm{P} 40$ \\
\hline P14 & 0.641 & P34 & P8 & P45 & \\
\hline P15 & 0.546 & $\mathrm{P} 1$ & $\mathrm{P} 11$ & $\mathrm{P} 40$ & \\
\hline P16 & 0.471 & P8 & $\mathrm{P} 40$ & $\mathrm{P} 45$ & \\
\hline P17 & 0.489 & P34 & $\mathrm{P} 8$ & $\mathrm{P} 45$ & \\
\hline P18 & 0.783 & $\mathrm{P} 40$ & P1 & $\mathrm{P} 11$ & \\
\hline P19 & 0.652 & P34 & P8 & $\mathrm{P} 45$ & \\
\hline $\mathrm{P} 20$ & 1.000 & $\mathrm{P} 20$ & & & \\
\hline P21 & 0.299 & $\mathrm{P} 1$ & P8 & $\mathrm{P} 40$ & \\
\hline $\mathrm{P} 22$ & 0.305 & P1 & P8 & $\mathrm{P} 40$ & \\
\hline $\mathrm{P} 23$ & 0.338 & P8 & P34 & $\mathrm{P} 45$ & \\
\hline $\mathrm{P} 24$ & 0.357 & P8 & P34 & $\mathrm{P} 45$ & \\
\hline $\mathrm{P} 25$ & 0.342 & P8 & P34 & $\mathrm{P} 45$ & \\
\hline P26 & 0.306 & P8 & P34 & $\mathrm{P} 45$ & \\
\hline P27 & 0.800 & P8 & $\mathrm{P} 45$ & & \\
\hline P28 & 0.373 & P34 & $\mathrm{P} 8$ & $\mathrm{P} 45$ & \\
\hline P29 & 0.657 & P47 & P11 & & \\
\hline P30 & 0.444 & $\mathrm{P} 1$ & P11 & $\mathrm{P} 40$ & \\
\hline P31 & 0.459 & P40 & P8 & $\mathrm{P} 1$ & \\
\hline P32 & 0.675 & P11 & P47 & & \\
\hline P33 & 0.545 & P34 & P8 & P45 & \\
\hline P34 & 1.000 & P34 & & & \\
\hline P35 & 1.000 & P35 & & & \\
\hline P36 & 0.947 & P45 & P34 & P8 & \\
\hline P37 & 0.885 & P8 & P34 & P45 & \\
\hline P38 & 0.919 & P8 & P34 & P45 & \\
\hline P39 & 0.685 & P34 & $\mathrm{P} 45$ & & \\
\hline P40 & 1.000 & P40 & & & \\
\hline P41 & 0.721 & P34 & P45 & & \\
\hline P42 & 0.552 & P8 & P40 & P1 & \\
\hline P43 & 0.598 & P40 & P8 & P45 & \\
\hline P44 & 1.000 & P44 & & & \\
\hline $\mathrm{P} 45$ & 1.000 & P45 & & & \\
\hline P46 & 0.693 & P40 & $\mathrm{P} 45$ & P47 & \\
\hline P47 & 1.000 & P47 & & & \\
\hline P48 & 0.569 & P34 & $\mathrm{P} 45$ & P47 & \\
\hline P49 & 1.000 & P49 & & & \\
\hline $\mathrm{P} 50$ & 1.000 & P8 & & & \\
\hline
\end{tabular}


Table 8. Potential for increasing output and reducing input in P2 DMU that is inefficient

\begin{tabular}{|c|c|c|c|c|}
\hline Variable & Original value & Radial movement & Slack movement & Projected value \\
\hline \multicolumn{5}{|c|}{ Average efficiency value $=0.725$} \\
\hline Production $(\mathrm{Kg})$ & 250 & 0 & 0 & 250 \\
\hline Income (IDR) & $1,113,254$ & 0 & $10,690.920$ & $1,123,944.920$ \\
\hline Seeds (IDR) & 715,000 & $-196,315.128$ & 0 & $518,684.872$ \\
\hline Input (IDR) & 466,100 & $-127,975.498$ & 0 & $338,124.502$ \\
\hline Outside employee & 460,000 & $-126,300.642$ & 0 & $333,699.358$ \\
\hline \multicolumn{2}{|r|}{ Peer } & \multicolumn{3}{|c|}{ Lambda weight } \\
\hline \multicolumn{2}{|r|}{ P8 } & \multicolumn{3}{|c|}{0.048} \\
\hline \multicolumn{2}{|r|}{$\mathrm{P} 1$} & \multicolumn{3}{|c|}{0.028} \\
\hline \multicolumn{2}{|r|}{$\mathrm{P} 40$} & \multicolumn{3}{|c|}{0.070} \\
\hline
\end{tabular}

The lack of non-family workers in the studied area had an impact on some farmers who were no longer productive while still engaged in farming activities. Farmers' productivity can upsurge with increasing age, can reach a maximum level, then decline (Abdulai and Eberlin, 2001). Economic problems, lifestyles and career perspectives (Gale, 2003) and precarious employment are generally characterized by shortterm contracts such as daily worker groups, homeworkers and part-time and temporary workers (Iwata, 2004) that are capable of underpinning young farmers who are reluctant to farm research area

\section{Improvement of supply chain efficiency of collector traders at village level}

The results of DMU efficiency calculation of the performance of garlic supply chain collectors at village level in Karanganyar Regency were worth 0.964 to 1 with an average efficiency level of 0.987. This indicates that almost all DMUs were efficient. Only two DMUs were inefficient and thus need to make improvements by decreasing inputs to reach an efficient point.

Three DMUs of traders at village level from a total of five DMUs had an efficiency value of one and three DMUs were peers for DMUs of other traders at village level, namely PD5, PD2 and PD4 (Table 9).

Table 9. Efficiency values and peers serving as the reference to each DMU of collector traders at village level in Karanganyar Regency

\begin{tabular}{cccc}
\hline DMU & Efficiency value & \multicolumn{2}{c}{ Peers } \\
\hline PD1 & 0.964 & PD5 & PD2 \\
PD2 & 1.000 & PD2 & \\
PD3 & 0.969 & PD5 & PD4 \\
PD4 & 1.000 & PD4 & \\
PD5 & 1.000 & PD5 & \\
\hline
\end{tabular}

One of the examples of village-level traders who were inefficient was PD3 with an efficiency value of 0.969 , which needs to refer to DMU peers of PD5 and PD4 to obtain efficient DMU (Table 10).

Table 10. Potential output increase and input reduction in inefficient PD3 DMUs

\begin{tabular}{lrrrr}
\multicolumn{1}{c}{ Variable } & Original value & Radial movement & Slack movement & Projected value \\
\hline Average efficiency value & 0.969 & & \\
Production (Kg) & 11,700 & 0 & 0 & 11,700 \\
Income (IDR) & $339,300,000$ & 0 & 0 & $339,300.000$ \\
Garlic purchase (IDR) & $187,200,000$ & $-5,753,536.042$ & 0 & $181,446,463.958$ \\
Loading/unloading and & $17,500,000$ & $-537,857.269$ & $-15,461,845.299$ & $1,500,297.433$ \\
drying (IDR) & & & 0 & $2,423,163.247$ \\
Transportation (IDR) & $2,500,000$ & $-76,836.753$ & \multicolumn{3}{c}{0.928} \\
\hline \multicolumn{2}{c}{ Peer } & & \multicolumn{3}{c}{0.687} \\
\hline
\end{tabular}


PD5 and PD4 were peers for village level collectors with the characteristics of having an average age of 50-60 years included in the productive age category with an average junior secondary education level and having an average experience of 7 years in trading garlic in village level.

Village level collectors are one of the suppliers in the supply chain business. Suppliers have an important role in customer perceptions of service and customer satisfaction (Cho et al., 2012). Supply chain management emphasizes the important role of buyer and supplier relations in supply chain management strategies (Tan, 2001), especially in the agricultural sector (Fischer et al., 2010).

\section{Improvement of supply chain efficiency of merchant traders at sub-district level}

The results of DMU efficiency calculation of the performance of garlic supply chain traders at the sub-district level in Karanganyar Regency were worth 0.882 to 1 . Two DMUs of trader collectors at sub-district level were not efficient and thus, they need to make improvements by lowering inputs to reach an efficient point. Two
DMUs of sub-district collectors from a total of four DMUs had an efficiency score of one and two DMUs were peers for DMUs of other sub-district traders, namely PK1 and PK3 (Table 11).

Table 11. Efficiency values and peers serving as the reference to each DMU of subdistrict level traders in Karanganyar Regency

\begin{tabular}{cccc}
\hline DMU & Efficiency value & \multicolumn{2}{c}{ Peers } \\
\hline PK1 & 1.000 & PK1 & \\
PK2 & 0.882 & PK1 & \\
PK3 & 1.000 & PK3 & \\
PK4 & 0.966 & PK3 & PK1 \\
\hline
\end{tabular}

One example of sub-district traders with efficient performance was the PK4 with an efficiency score of 0.966 , which needs to refer to PK3 and PK1 DMU peers, so that the DMU can become efficient (Table 12). Peers at the subdistrict level, traders PK1 and PK3, had an average age of 60 years old included in the productive age category with an average high school education level and an average experience of 5 years in trading garlic at the sub-district level.

Table 12. Potential increased output and reduced input in inefficient PK3 DMUs

\begin{tabular}{lrrrr}
\hline \multicolumn{1}{c}{ Variable } & Original value & Radial movement & Slack movement & Projected value \\
\hline Average efficiency value $=0,966$ & 9,150 & 0 & 0 & 9,150 \\
Production (Kg) & $263,350,000$ & 0 & $2,000,000.000$ & $265,350,000.000$ \\
$\begin{array}{l}\text { Income (IDR) } \\
\text { Garlic purchase (IDR) }\end{array}$ & $155,550,000$ & $-5,231,375.623$ & 0 & $150,318,624.377$ \\
Loading/unloading & 950,000 & $-31,949.899$ & $-91,880.508$ & $826,169.593$ \\
and drying (IDR) & & & 0 & $1,449,552.791$ \\
Transportation (IDR) & $1,500,000$ & $-5,0447.209$ & \multicolumn{3}{c}{ Lambda weight } \\
\hline \multicolumn{2}{c}{ Peer } & & 0.871 \\
\hline & PK3 & & 0.095 \\
\hline
\end{tabular}

Trader collectors at regency level have an important role in establishing efficient supply chain management in Karanganyar Regency because the contribution of traders at the subdistrict level is intermediaries from consumers outside the Karanganyar Regency area. Regency level traders cannot be analyzed because there is only one trader exists in the studied area.

\section{Improved retail supply chain efficiency}

The result of DMU efficiency calculation at the retail level of the garlic supply chain performance in Karanganyar Regency was 1, meaning that the supply chain actors were efficient. Efficiency refers to how well resources are used (Lai et al., 2002). The speed of delivery and quality of garlic is one of the important indicators in supply chain efficiency (Persson and Olhager, 2002; Rong et al., 2011). Retailers in the studied area bought garlic directly from farmers without going through collectors and sold the garlic directly to the nearest market.

One of the advantages of supply chain management is being able to compete in the supply chain business (Rahimnia and Moghadasian, 2010; Lee et al., 2011; Skandrani 
et al., 2011; Kazemzadeh et al., 2012; Zhang and Huo, 2013), as well as being able to manage the relationship between buyers and suppliers, not only from the purchasing function, so that supply chain businesses between actors can run longterm (Chakraborty et al., 2014).

\section{CONCLUSIONS}

The results presented in the previous chapter have shown that the most efficient actors were retailers with an average efficiency value of 1 . The most inefficient actors were farmers with an average efficiency value of 0.709 .13 DMUs from 50 DMUs were efficient, while the remaining 37 DMUs need to make improvements to achieve efficient point. Improvements at the farm level to increase output values can be done by reducing inputs, using certified seeds and suitable fertilizer recommendations and reducing external labor during the process of maintenance, harvest and post-harvest. Farmers are expected to have the desire to learn from referral farmers. Improvements in village and sub-district level traders are reductions in inputs, i.e. reducing the number of garlic purchases from previous actors. It is intended that the price of garlic at the level of end consumers is not too high. Further research is needed regarding the performance of the garlic supply chain at the level of end consumers.

\section{REFERENCES}

Abdulai, A., \& Eberlin, R. (2001). Technical efficiency during economic reform in Nicaragua: Evidence from farm household survey data. Economic Systems, 25(2), 113125. https://doi.org/10.1016/S0939-3625(01)0 0010-3

Baltacioglu, T., Ada, E., Kaplan, M. D., And, Y., $\&$ Kaplan, Y. C. (2007). A new framework for service supply chains. The Service Industries Journal, 27(2), 105-124. https://doi.org/ $10.1080 / 02642060601122629$

Bastas, A., \& Liyanage, K. (2018). Sustainable supply chain quality management: A systematic review. Journal of Cleaner Production, 181, 726-744. https://doi.org/10. 1016/j.jclepro.2018.01.110

Batt, P. J. (2009). Supply chain management: concepts and application within the transitional economies. Banwa, 6(1), 1-13. https://doi.org/10.3860/banwa.v6i1.1953

Benkeblia, N. (2004). Antimicrobial activity of essential oil extracts of various onions (Allium cepa) and garlic (Allium sativum). LWT - Food Science and Technology, 37(2), 263-268. https://doi.org/10.1016/j.lwt.2003.09.001

BPS-Statistics of Jawa Tengah Province. (2020). Harvested area of vegetables by regency/ municipality and kind of plant in Jawa Tengah Province, 2018 and 2019. Retrieved from https://jateng.bps.go.id/statictable/2020/06/22 /1819/luas-panen-tanaman-sayuran-menurutkabupaten-kota-dan-jenis-tanaman-di-provin si-jawa-tengah-2018-dan-2019.html

Burton, R. J. F. (2006). An alternative to farmer age as an indicator of life-cycle stage: The case for a farm family age index. Journal of Rural Studies, 22(4), 485-492. https://doi.org/10.1 016/j.jrurstud.2006.02.005

Chakraborty, S., Bhattacharya, S., \& Dobrzy kowski, D. D. (2014). Impact of supply chain collaboration on value co-creation and firm performance: a healthcare service sector perspective. Procedia Economics and Finance, 11(14), 676-694. https://doi.org/10. 1016/s2212-5671(14)00233-0

Charnes, A., Cooper, W. W., \& Rhodes, E. (1978). Measuring the efficiency of decision making units. European Journal of Operational Research, 2(6), 429-444. https:// doi.org/10.1016/0377-2217(78)90138-8

Cho, D. W., Lee, Y. H., Ahn, S. H., \& Hwang, M. K. (2012). A framework for measuring the performance of service supply chain management. Computers and Industrial Engineering, 62(3), 801-818. https://doi.org/ 10.1016/j.cie.2011.11.014

Chopra, S., \& Meindl, P. (2001). Supply chain management: strategy, planning, and operation. New Jersey: Prentice Hall.

Chopra, S., \& Meindl, P. (2007) Supply chain management. strategy, planning \& operation. In: Boersch C., Elschen R. (eds) Das Summa Summarum des Management. Gabler. https:// doi.org/10.1007/978-3-8349-9320-5_22

De Fazio, M. (2016). Agriculture and sustainability of the welfare: the role of the short supply chain. Agriculture and 
Agricultural Science Procedia, 8, 461-466. https://doi.org/10.1016/j.aaspro.2016.02.044

Fantazy, K. A., Kumar, V., \& Kumar, U. (2010). Supply management practices and performance in the Canadian hospitality industry. International Journal of Hospitality Management, 29(4), 685-693. https://doi.org/ 10.1016/j.ijhm.2010.02.001

Fischer, C., Hartmann, M., Reynolds, N., Leat, P. M. K., Revoredo-Giha, C., Henchion, M., Gracia, A., Albisu, L. M., Fischer, C. (Ed.), \& Hartmann, M. (Ed.) (2010). Determinants of sustainable agri-food chain relationships in Europe. In C. Fischer, \& M. Hartmann (Eds.), Agri-food Chain Relationships (pp. 119 - 134). CABI Publishing. Retrieved from https:// www.cabi.org/cabebooks/ebook/2010325106 2

Gale, H. F. (2003). Age-specific patterns of exit and entry in U.S. farming, 1978-1997. Review of Agricultural Economics, 25(1), 168-186. Retrieved from https://www.jstor.org/stable/ 1349870

Furqon, C. (2014). Analisis manajemen dan kinerja rantai pasokan agribisnis buah stroberi di Kabupaten Bandung. Analisis Manajemen dan Kinerja Rantai Pasokan Agribisnis, 3(2), 109-126. Retrieved from https://ejournal. upi.edu/index.php/image/article/view/1119

Haciseferoğullari, H., Özcan, M., Demir, F., \& Çalişir, S. (2005). Some nutritional and technological properties of garlic (Allium sativum L.). Journal of Food Engineering, 68(4), 463-469. https://doi.org/10.1016/j.jfoo deng.2004.06.024

Ibrahim, S. B., \& Hamid, A. A. (2012). Supply chain management practices and supply chain performance effectiveness. International Journal of Science and Research (IJSR), 3(8), 187-195. Retrieved from https://www.research gate.net/publication/311312211_Supply_Chai n_Management_Practices_and_Supply_Chain _Performance_Effectiveness

Iwata, K. (2004). Diverse working conditions among non-standard employees : JIL research report and policy implications. Japan Labor Review, 1(1), 77-91. Retrieved from https:// www.jil.go.jp/english/JLR/documents/2004/J LR01_iwata.pdf
Kazemzadeh, R. B., Sepehri, M. M., \& Jahantigh, F. F. (2012). Design and analysis of a health care supply chain management. Advanced Materials Research, 433-440, 2128-2134. https://doi.org/10.4028/www.scientific.net/am r.433-440.2128

Lai, K. H., Ngai, E. W. T., \& Cheng, T. C. E. (2002). Measures for evaluating supply chain performance in transport logistics. Transportation Research Part E: Logistics and Transportation Review, 38(6), 439-456. https: //doi.org/10.1016/S1366-5545(02)00019-4

Lee, J., \& Spratling, R. (2019). Recruiting mothers of children with developmental disabilities: adaptations of the snowball sampling technique using social media. Journal of Pediatric Health Care, 33(1), 107110. https://doi.org/10.1016/j.pedhc.2018.09.0 11

Lee, S. M., Lee, D. H., \& Schniederjans, M. J. (2011). Supply chain innovation and organizational performance in the healthcare industry. International Journal of Operations and Production Management, 31(11), 1193 1214. https://doi.org/10.1108/0144357111117 8493

Liang, L., Yang, F., Cook, W. D., \& Zhu, J. (2006). DEA models for supply chain efficiency evaluation. Annals of Operations Research, 145, 35-49. https://doi.org/10.1007/ s10479-006-0026-7

Lovász, A., \& Rigó, M. (2013). Vintage effects, aging and productivity. Labour Economics, 22, 47-60. https://doi.org/10.1016/j.labeco.20 12.08.005

Nurdiani, N. (2014). Teknik sampling snowball dalam penelitian lapangan. ComTech: Computer, Mathematics and Engineering Applications, 5(2), 1110. https://doi.org/10.21 512/comtech.v5i2.2427

Peng wong, W., \& Yew wong, K. (2011). Supply chain management, knowledge management capability and their linkages towards firm performance. Business Process Management Journal, 17(6), 940-964. https://doi.org/10. $1108 / 14637151111182701$

Persson, F., \& Olhager, J. (2002). Performance simulation of supply chain designs. International Journal of Production 
Economics, 77(3), 231-245. https://doi.org/ 10.1016/S0925-5273(00)00088-8

Petropoulos, S. A., Fernandes, Â., Ntatsi, G., Petrotos, K., Barros, L., \& Ferreira, I. C. F. R. (2018). Nutritional value, chemical characterization and bulb morphology of Greek Garlic landraces. Molecules, 23(2), 1-14. https://doi.org/10.3390/molecules23020319

Rahimnia, F., \& Moghadasian, M. (2010). Supply chain leagility in professional services: how to apply decoupling point concept in healthcare delivery system. Supply Chain Management, 15(1), 80-91. https://doi.org/10.1108/1359854 1011018148

Rong, A., Akkerman, R., \& Grunow, M. (2011). An optimization approach for managing fresh food quality throughout the supply chain. International Journal of Production Economics, 131(1), 421-429. https://doi.org/ 10.1016/j.ijpe.2009.11.026

Sadler, G. R., Lee, H. C., Lim, R. S. H., \& Fullerton, J. (2010). Recruitment of hard-toreach population subgroups via adaptations of the snowball sampling strategy. Nursing and Health Sciences, 12(3), 369-374. https://doi. org/10.1111/j.1442-2018.2010.00541.x

Sari, S. W., Nurmalina, R., \& Setiawan, B. (2014). Efisiensi kinerja rantai pasok ikan lele di Indramayu, Jawa Barat. Jurnal Manajemen \& Agribisnis, 11(1), 12-23. Retrieved from https://journal.ipb.ac.id/index.php/jmagr/articl e/view/8494

Sigala, M. (2008). A supply chain management approach for investigating the role of tour operators on sustainable tourism: the case of TUI. Journal of Cleaner Production, 16(15), 1589-1599. https://doi.org/10.1016/j.jclepro.2 008.04.021

Skandrani, H., Triki, A., \& Baratli, B. (2011). Trust in supply chains, meanings, determinants and demonstrations: A qualitative study in an emerging market context. Qualitative Market Research: An International Journal, 14(4), 391-409. https://doi.org/10.1108/1352275111 1163227

Sugiyono. (2014). Metode penelitian kuantitatif, kualitatif, dan $R \& D$. Bandung: Alfabeta.
Sukmaningrum, A., \& Imron, A. (2017). Memanfaatkan usia produktif dengan usaha kreatif industri pembuatan kaos pada Remaja. Paradigma, 5(3), 1-6. Retrieved from https://jurnalmahasiswa.unesa.ac.id/index.php /paradigma/article/view/21647

Tan, K. C. (2001). A framework of supply chain management literature. European Journal of Purchasing and Supply Management, 7(1), 39-48. https://doi.org/10.1016/S0969-7012(0 0)00020-4

Thakkar, J., Kanda, A., \& Deshmukh, S. G. (2009). Supply chain performance measurement framework for small and medium scale enterprises. Benchmarking: An International Journal, 16(5), 702-723. https://doi.org/10.11 08/14635770910987878

Tippayawong, K. Y., Niyomyat, N., Sopadang, A., \& Ramingwong, S. (2016). Factors affecting green supply chain operational performance of the Thai auto parts industry. Sustainability (Switzerland), 8(11), 1161. https://doi.org/10.3390/su8111161

Wongnaa, C. A., \& Awunyo-vitor, D. (2017). Scale efficiency of maize farmers in four agro ecological zones of Ghana: A parametric approach. Journal of the Saudi Society of Agricultural Sciences, 18(3), 275-287. https:// doi.org/10.1016/j.jssas.2017.08.003

Wu, C., Wang, M., Dong, Y., Cheng, Z., \& Meng, H. (2015). Growth, bolting and yield of garlic (Allium sativum L.) in response to clove chilling treatment. Scientia Horticulturae, 194(14), 43-52. https://doi.org/10.1016/j.scie nta.2015.07.018

Zhang, M., \& Huo, B. (2013). The impact of dependence and trust on supply chain integration. International Journal of Physical Distribution \&amp; Logistics Management, 43(7), 544-563. https://doi.org/10.1108/IJPD LM-10-2011-0171

Zhang, X., Song, H., \& Huang, G. Q. (2009). Tourism supply chain management: A new research agenda. Tourism Management, 30(3), 345-358. https://doi.org/10.1016/j.tourman.20 08.12 .010 
Appendix 1. Harvest area and garlic production by regency / city of Central Java Province in 2018

\begin{tabular}{|c|c|c|c|}
\hline No. & Regency/City & Harvest area (ha) & Production (ton) \\
\hline 1. & Cilacap Regency & 10 & 27.8 \\
\hline 2. & Banyumas Regency & 0 & 0.0 \\
\hline 3. & Purbalingga Regency & 2 & 0.3 \\
\hline 4. & Banjarnegara Regency & 0 & 0.0 \\
\hline 5. & Kebumen Regency & 0 & 0.0 \\
\hline 6. & Purworejo Regency & 0 & 0.0 \\
\hline 7. & Wonosobo Regency & 3 & 226.9 \\
\hline 8. & Magelang Regency & 335 & $2,052.5$ \\
\hline 9. & Boyolali Regency & 0 & 0.0 \\
\hline 10. & Klaten Regency & 0 & 0.0 \\
\hline 11. & Sukoharjo Regency & 0 & 0.0 \\
\hline 12. & Wonogiri Regency & 0 & 0.0 \\
\hline 13. & Karanganyar Regency & 206 & $1,677.9$ \\
\hline 14. & Sragen Regency & 0 & 0.0 \\
\hline 15. & Grobogan Regency & 0 & 0.0 \\
\hline 16. & Blora Regency & 0 & 0.0 \\
\hline 17. & Rembang Regency & 0 & 0.0 \\
\hline 18. & Pati Regency & 0 & 0.0 \\
\hline 19. & Kudus Regency & 0 & 0.0 \\
\hline 20. & Jepara Regency & 0 & 0.0 \\
\hline 21. & Demak Regency & 0 & 0.0 \\
\hline 22. & Semarang Regency & 1 & 4.0 \\
\hline 23. & Temanggung Regency & 1,748 & $13,779.1$ \\
\hline 24. & Kendal Regency & 3 & 14.5 \\
\hline 25. & Batang Regency & 4 & 6.6 \\
\hline 26. & Pekalongan Regency & 0 & 0.0 \\
\hline 27. & Pemalang Regency & 0 & 0.0 \\
\hline 28. & Tegal Regency & 211 & 1.663 .8 \\
\hline 29. & Brebes Regency & 15 & 93.8 \\
\hline 1. & Magelang City & 0 & 0.0 \\
\hline 2. & Surakarta City & 0 & 0.0 \\
\hline 3. & Salatiga City & 0 & 0.0 \\
\hline 4. & Semarang City & 0 & 0.0 \\
\hline 5. & Pekalongan City & 0 & 0.0 \\
\hline 6. & Tegal City & 0 & 0.0 \\
\hline
\end{tabular}

Source: BPS-Statistics of Jawa Tengah Province, 2020 